\title{
Spatial and Temporal Changes in Nitrogen, Phosphorus and Potassium Concentration in Water in the Thirappane Tank Cascade in Dry Zone of Sri Lanka
}

\author{
W. M. G. D. Wijesundara ${ }^{\#}$ K. A. Nandasena and A. N. Jayakody \\ Dept. of Soil Science, Faculty of Agriculture, \\ University of Peradeniya, Peradeniya, Sri Lanka \\ ${ }^{\#}$ Corresponding Author:
}

Tel: (94) 71827 2871; Fax: (94) 25226 6512; Email: geethikawijesundara@yahoo.com

\begin{abstract}
This study was conducted to assess spatial and temporal changes of major plant nutrients; nitrogen $\left(\mathrm{NO}_{3}{ }^{-} \mathrm{N}\right)$, phosphorus $\left(\mathrm{PO}_{4}{ }^{3-}-\mathrm{P}\right)$ and potassium $\left(\mathrm{K}^{+}\right)$in the Thirappane tank cascade system. Three tanks namely Meegasagama, Alistana and Thirappane and drain channel in two rice cultivated tracks in between three tanks were selected for water sampling. Sampling was done monthly intervals from nine locations. In all water samples, dissolved $\mathrm{NO}_{3}{ }^{-} \mathrm{N}, \mathrm{PO}_{4}{ }^{3-}-\mathrm{P}$ and $\mathrm{K}^{+}$were determined using standard laboratory techniques. $\mathrm{NO}_{3}^{-}-\mathrm{N}, \mathrm{PO}_{4}{ }^{3-}-\mathrm{P}$ and $\mathrm{K}^{+}$concentrations in water created significant spatial changes from upper tank to lower tank of cascade. All three plant nutrients showed a significant steady increase from upper tank Meegasagama to middle tank Alistana and then to lower tank Thirappane and waters of three sampling points of two paddy tracks. As temporal changes, it was found that $\mathrm{NO}_{3}^{-}-\mathrm{N}, \mathrm{PO}_{4}^{3-} \mathrm{P}$ and $\mathrm{K}^{+}$concentrations of waters of these three tanks and sampling points showed a bimodal pattern which was coincided with the bimodal rainfall of the dry zone. Highest concentration of nutrients was observed in months of April and May in Yala compared to the Maha season. Low nutrients concentration in the Maha period could be due to dilution effect caused by comparatively high volume of tank water during Maha season.
\end{abstract}

KEYWORDS: Plant nutrients, Tank cascade system, Surface water

\section{Introduction}

The landscape of dry zone of Sri Lanka is scattered with about 12,000 tanks that have been the back bone of the irrigation system for centuries. Of all the small tanks in the Dry zone, approximately 90 percent is clustered in to the cascades. A tank cascade is a series of small tanks that are constructed at successive locations down one single common water course (Figure 1). Each of the cascade forms a distinct small watershed ranging in extent from 5 to 10 square miles (Pannabokke, 2002). This type of tank irrigation system is found in the Northern part of Thailand and the Southern parts of the India and Sri Lanka (Shinogi, 2001). 
Tank cascade irrigation system provides a continuous water flow from upper tank to lower tank through cultivated lands and through tank thaulla area which is the area situated just above the tank bed and covered with numerous varieties of plants and creepers.

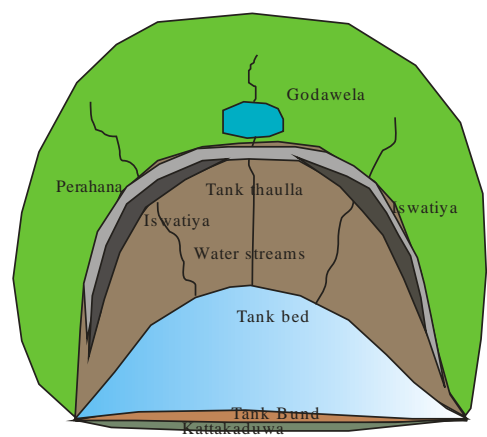

\section{Figure 1: Features of the ancient tank village system}

Traditional tank cascade system has many macros and micro land uses which such as perahana, godawela, gasgommana, kattakaduwa iswatiya and has specific duty on saving and sustaining this system for a long time. Major importance of most of these features located in and above tank thaulla is filtering the sediment flow coming from upstream lands and prevents entering eroded soil from upper land slopes (Dharmasena, 2004).Rice is the main crop cultivates under the tank cascade irrigation system. Nitrogen $(\mathrm{N})$, Phosphorus $(\mathrm{P})$ and Potassium $(\mathrm{K})$ are the major nutrients added intensively as chemical fertilizer for rice cultivation in Sri Lanka. According to the Department of Agriculture recommendation, farmers apply $252 \mathrm{~kg}$ urea, $84 \mathrm{~kg}$ triple super phosphate and $72 \mathrm{~kg}$ muriate of potash and $4.8 \mathrm{~kg}$ of zinc sulfate per hectare per cropping season. Runoff water and sediments are the most important factors which carry nutrients such as $\mathrm{N}$ and $\mathrm{P}$ from agricultural lands affecting the quality of tanks and streams water (Turner and Rabelais, 2004).

$\mathrm{N}$ and $\mathrm{P}$ play a significant role with regards to ecological and economic aspects, especially through tank eutrophication and transport from upper tank to the bottom tank of the cascade system (William et al., 2008). The equilibrium state of a tank, in relation to the water quality, could be disrupted by the intensive agricultural practices and human activities escalated with the growing population. Accumulation of nutrients in tank water due to the added fertilizers and dung and urine of the large cattle population could degrade water quality thus bringing in potential hazards to the human health (Young et al., 2009).

As the village tanks of the dry zone are basically used for domestic needs as well as for irrigation, frequent monitoring of the possible enrichment of tank water with plant nutrients and changes in water quality parameters is required. In the tank cascade system, no systematic work, however, has been carried out on water quality aspects particularly on the accumulation and fluctuation of plant nutrients. 
Therefore the main purpose of this research is to study the characteristics of nutrient movement along Thirappane tank cascade in the Dry Zone of Sri Lanka.

\section{Materials and Methods}

Field work has been carried out in the Thirappane area located about $20 \mathrm{~km}$ south from Anuradhapura city in the North Central Province. Thirappane tank cascade consists of six connected tanks representing a" linear type cascade" and the command area of the whole is about $8 \mathrm{~km}$ in length and $2 \mathrm{~km}$ in width. Main tanks located along main axis in Thirappane cascade, namely Meegasagama, Alistana and Thirappane were selected for this study (Figure 2).

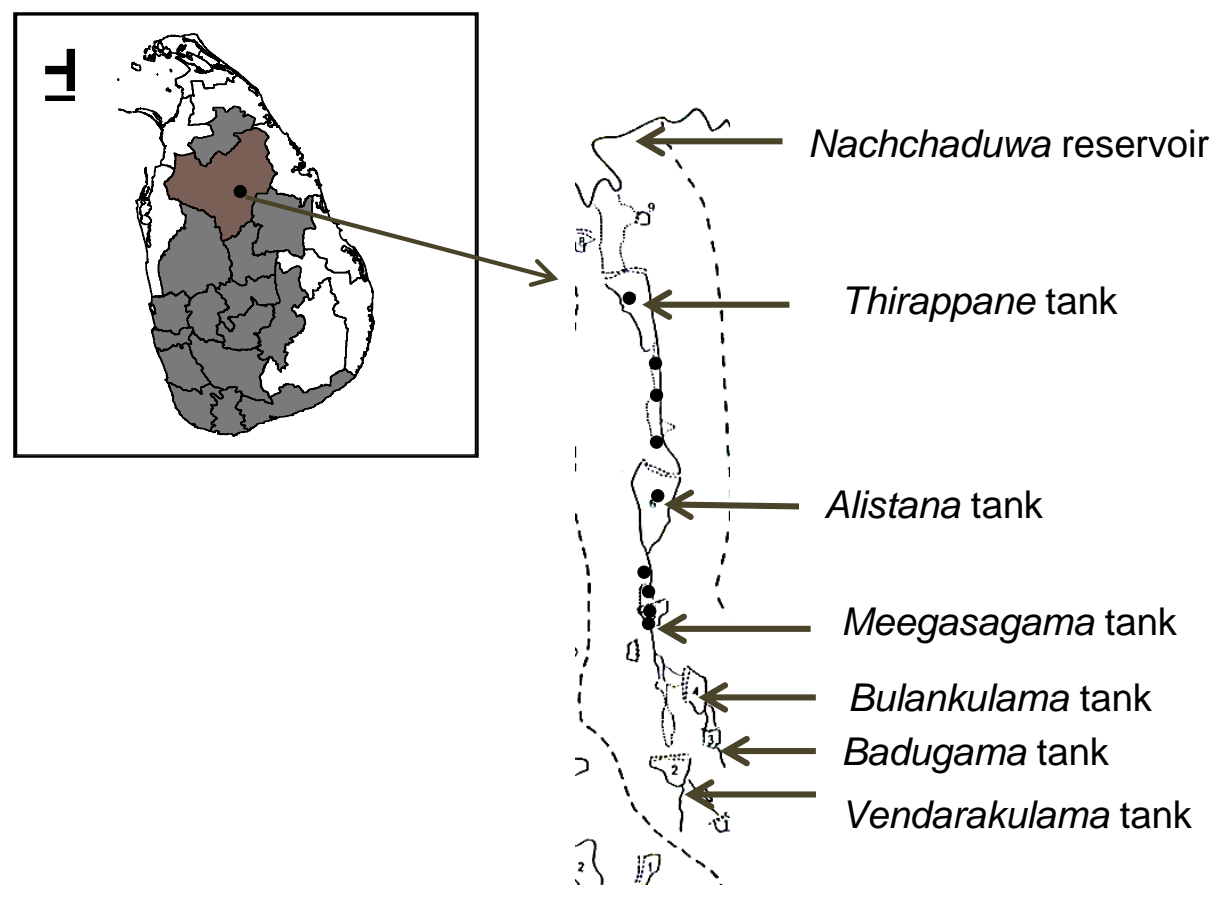

Figure 2: Thirappane tank cascade and sampling locations

Three sampling points in paddy fields under each tank were selected based on a preliminary survey to represent the respective areas. Water sampling was carried out for one year from February 2010 to January 2011 at monthly intervals from the selected locations using clean plastic bottles. The chemical analysis of the collected samples was conducted at the Department of Soil Science, University of Peradeniya. There were three replicates for each chemical analysis.

In all water samples, dissolved $\mathrm{NO}_{3}{ }^{-}-\mathrm{N}$ and $\mathrm{PO}_{4}{ }^{3-}-\mathrm{P}$ were determined using sodium salicylate (Bremner et al., 1982) and Molybdate blue colorimetric procedures (Murphy and Relay, 1962) respectively. Potassium determination was done using Flame Emission Spectrophotometer. $\mathrm{pH}$ and the electrical conductivity (EC) of 
water samples were also measured. The data were analyzed statistically using SAS software package (GLM procedure and t Tests (LSD).

\section{Results and Discussion}

The results of the concentrations of plant nutrients in water samples of the Thirappane cascade from February 2010 to January 2011 are given in Tables 01, 02 and 03. According to the results, concentration of major plant nutrients showed significant spatial and temporal variations over the study period.

In dry zone, there are two distinct cropping seasons namely Yala and Maha based on the rainfall distribution. Yala and maha seasons fall in the months of May to September and October to March respectively. In the Yala season, land preparation for paddy cultivation is carried out in late April to early May and planting begins in early weeks of May. In this period, fertilizers are applied as basal and top dressings to the fields. It was reported that the quantity of urea application varies from 100 to $150 \mathrm{~kg} / \mathrm{ac}$ and Triple Super Phosphate application ranged from 75 to $100 \mathrm{~kg} / \mathrm{ac}$. (Young et al, 2009). Also application of excess amount of fertilizer resulted in enhancement of nutrient content in the surface runoff (Chun et al., 2003).

In this study, $\mathrm{NO}_{3}{ }^{-} \mathrm{N}$ concentration of tank water and water samples collected from canal along the rice field varied from $2.34-6.98 \mathrm{mgL}^{-1}$ (Table 1). All sampling points along canals and in tanks showed high amounts of $\mathrm{NO}_{3}{ }^{-} \mathrm{N}$ during April to June which falls within the Yala season. The peak of $\mathrm{NO}_{3}{ }^{-} \mathrm{N}$ concentration was observed just after the application of chemical fertilizers and then decreased gradually (April, May, June, July and August).

However, $\mathrm{NO}_{3}{ }^{-}-\mathrm{N}$ concentrations of water of the tanks in most instances showed a significant steady increasing trend from Meegasagama (upmost) to Alistana (middle) and then to Thirappane tank (lowest) (Figure 2). This increasing trend of $\mathrm{NO}_{3}{ }^{-} \mathrm{N}$ in the waters of the tanks towards the Thirappane tank could be attributed to the continuous enrichment of nutrients from the applied fertilizers in the commanding areas which are mainly under rice and from the naturally accumulated cow dung and urine in the thaulla and surrounding areas of the cascade system. Mechanism by which the nutrients, particularly $\mathrm{N}$ and $\mathrm{P}$, are added to the tank water is through runoff and sediments. This significant increase from Meegasagama to Thirappane was observed clearly during the periods of rainy months and irrigation (Figure 3a). This may have been due to the higher rate of irrigation water passing through paddy lands carrying relatively high amount of nitrogen from chemical fertilizer. 
Table 1: Temporal and spatial variability of Nitrate nitrogen $\left(\mathrm{NO}_{3}{ }^{-} \mathrm{N} \mathrm{mgL}^{-1}\right)$ movement during 2010 - 2011

\begin{tabular}{|c|c|c|c|c|c|c|c|c|c|c|c|c|}
\hline & Feb & Mar & April & May & June & July & Aug & Sep & Oct & Nov & Dec & Jan \\
\hline Mee tank & $3.12_{\mathrm{H}}^{\mathrm{f}}$ & $4.19_{\mathrm{F}}^{\mathrm{f}}$ & $4.64_{D} f$ & $5.44_{A^{g}}$ & $4.72_{\mathrm{D}}^{\mathrm{e}}$ & $3.52_{\mathrm{G}}^{\mathrm{e}}$ & $4.11_{\mathrm{F}}^{\mathrm{a}}$ & $3.49_{\mathrm{G}}^{\mathrm{d}}$ & $5.21_{\mathrm{AB}}{ }^{\mathrm{d}}$ & $4.30_{\mathrm{E}}^{\mathrm{g}}$ & $4.20_{\mathrm{F}}^{\mathrm{d}}$ & $4.92_{\mathrm{C}}^{\mathrm{a}}$ \\
\hline Field R1 & $3.13_{\mathrm{H}}{ }^{\text {ef }}$ & $4.23_{\mathrm{E}}^{\mathrm{ef}}$ & $4.85_{\mathrm{C}}^{\mathrm{e}}$ & $5.68_{\mathrm{A}}{ }^{\mathrm{f}}$ & $4.76_{\mathrm{CD}}^{\mathrm{e}}$ & $3.72_{\mathrm{F}}^{\mathrm{cd}}$ & $3.95_{\mathrm{EF}}^{\mathrm{a}}$ & $3.54_{\mathrm{G}}{ }^{\mathrm{cd}}$ & $5.26_{\mathrm{B}}^{\mathrm{d}}$ & $4.52_{D}{ }^{f}$ & $4.35_{\mathrm{E}}^{\mathrm{c}}$ & $3.95_{\mathrm{EF}}^{\mathrm{d}}$ \\
\hline Field R2 & $3.24_{\mathrm{H}}^{\mathrm{e}}$ & $4.29_{\mathrm{FG}}{ }^{\mathrm{de}}$ & $5.18_{C}{ }^{d}$ & $5.91_{\mathrm{A}}^{\mathrm{e}}$ & $5.08_{\mathrm{CD}}^{\mathrm{cd}}$ & $3.90_{\mathrm{GH}}{ }^{\mathrm{a}}$ & $4.08_{\mathrm{G}}{ }^{\mathrm{a}}$ & $3.64_{\mathrm{H}}^{\mathrm{b}}$ & $5.57_{\mathrm{B}}^{\mathrm{c}}$ & $4.87_{\mathrm{D}}^{\mathrm{e}}$ & $4.56_{\mathrm{E}}^{\mathrm{b}}$ & $4.28_{\mathrm{FG}}^{\mathrm{c}}$ \\
\hline Field R3 & $3.43_{\mathrm{H}}^{\mathrm{bcd}}$ & $4.38_{\mathrm{E}}^{\mathrm{c}}$ & $5.62_{\mathrm{BC}}^{\mathrm{b}}$ & $6.42_{\mathrm{A}}^{\mathrm{c}}$ & $5.47_{C}^{b}$ & $3.87_{\mathrm{F}}^{\mathrm{ab}}$ & $3.70_{\mathrm{G}}^{\mathrm{b}}$ & $3.80_{\mathrm{FG}}^{\mathrm{a}}$ & $5.90_{\mathrm{B}}^{\mathrm{b}}$ & $5.87_{\mathrm{B}}^{\mathrm{c}}$ & $4.85_{\mathrm{D}}^{\mathrm{a}}$ & $4.41_{\mathrm{E}}^{\mathrm{b}}$ \\
\hline Alis tank & $3.36_{\mathrm{G}}^{\mathrm{d}}$ & $4.32_{\mathrm{E}}^{\mathrm{cd}}$ & $4.87_{\mathrm{D}}^{\mathrm{e}}$ & $5.96_{\mathrm{A}}^{\mathrm{de}}$ & $4.96_{D}{ }^{d}$ & $3.64_{\mathrm{F}}^{\mathrm{d}}$ & $2.43_{\mathrm{H}}^{\mathrm{e}}$ & ${ }_{\mathrm{d}}^{3.55_{\mathrm{FG}}}{ }^{\mathrm{c}}$ & $5.33_{C^{d}}$ & $5.63_{B}^{d}$ & $3.55_{\mathrm{FG}^{\mathrm{g}}}^{\mathrm{g}}$ & $3.30_{\mathrm{G}}{ }^{\mathrm{g}}$ \\
\hline Field R1 & $3.38_{\mathrm{H}}{ }^{\mathrm{cd}}$ & $4.39_{\mathrm{E}}^{\mathrm{c}}$ & $5.09_{D}^{d}$ & $6.10_{\mathrm{A}}^{\mathrm{d}}$ & $5.17_{\mathrm{D}}^{\mathrm{c}}$ & $3.71_{\mathrm{FG}}{ }^{\mathrm{cd}}$ & $2.34_{\mathrm{I}}^{\mathrm{e}}$ & $3.50_{\mathrm{H}}{ }^{\mathrm{d}}$ & $5.35_{\mathrm{C}}^{\mathrm{d}}$ & $5.69_{B}^{d}$ & $3.73_{\mathrm{FG}}{ }^{\mathrm{f}}$ & $3.41_{\mathrm{H}}{ }^{\mathrm{f}}$ \\
\hline Field R2 & $3.50_{\mathrm{F}}^{\mathrm{b}}$ & $4.56_{\mathrm{D}}^{\mathrm{b}}$ & $5.43^{c}$ & $6.75_{\mathrm{A}}^{\mathrm{b}}$ & $5.53_{C^{b}}^{b}$ & $3.73_{\mathrm{EF}}{ }^{\mathrm{cd}}$ & $2.44_{\mathrm{G}}^{\mathrm{de}}$ & $3.58_{\mathrm{F}}^{\mathrm{bc}}$ & $5.67_{C}^{c}$ & $5.90_{\mathrm{B}}^{\mathrm{c}}$ & $3.86_{\mathrm{E}}{ }^{\mathrm{f}}$ & $3.63_{\mathrm{EF}}^{\mathrm{e}}$ \\
\hline Field R3 & $3.71_{\mathrm{F}}^{\mathrm{a}}$ & $4.86_{D}^{a}$ & $5.85_{\mathrm{C}}^{\mathrm{a}}$ & $6.98_{\mathrm{A}}^{\mathrm{a}}$ & $5.84_{C^{a}}$ & $3.76_{\mathrm{F}}^{\mathrm{c}}$ & $2.73_{\mathrm{G}}^{\mathrm{c}}$ & $3.82_{\mathrm{EF}^{\mathrm{a}}}^{\mathrm{a}}$ & $6.37_{\mathrm{B}}^{\mathrm{a}}$ & $6.44_{B}{ }^{a}$ & $4.04_{\mathrm{EF}}^{\mathrm{e}}$ & $3.93_{\mathrm{EF}}^{\mathrm{d}}$ \\
\hline Thi tank & $3.49_{\mathrm{G}}^{\mathrm{bc}}$ & $4.48_{\mathrm{E}}^{\mathrm{b}}$ & $5.11_{D}^{d}$ & $6.77_{\mathrm{A}}^{\mathrm{b}}$ & $5.82_{C^{a}}{ }^{a}$ & $3.76_{\mathrm{F}}^{\mathrm{bc}}$ & $2.59_{\mathrm{H}}{ }^{\mathrm{cd}}$ & $3.57_{\mathrm{G}}^{\mathrm{bc}}$ & $5.61_{C}{ }^{c}$ & $6.14_{B}^{b}$ & $3.78_{\mathrm{F}} \mathrm{f}$ & $3.69_{\mathrm{FG}}^{\mathrm{e}}$ \\
\hline
\end{tabular}

Means with same letters are not statistically significant (Lowercase letters- Temporal variation, Upper case letters- Spatial variation). (Thi tank- Thirappane tank, Alis tank- Alisthana tank, Mee tank- Meegasagama tank. 


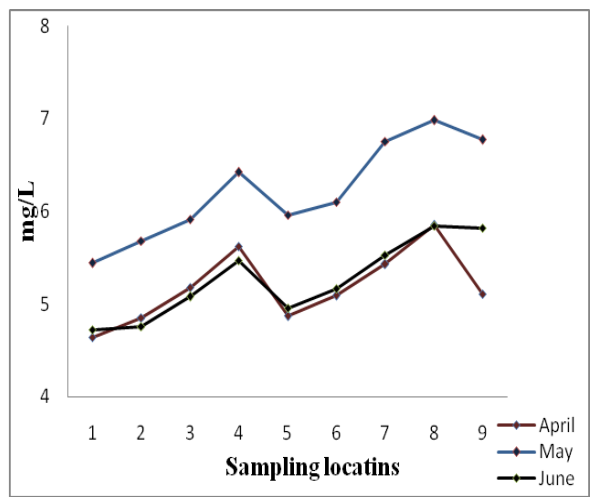

Figure 3a: Change in $\mathrm{NO}_{3}$ concentration during irrigation

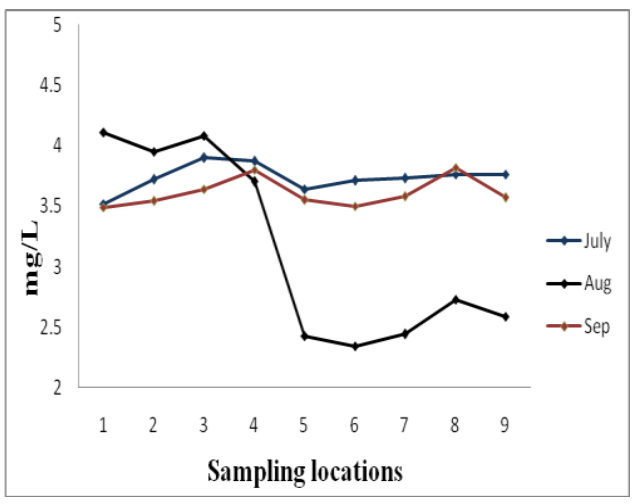

Figure 3b: Change in $\mathrm{NO}_{3}{ }^{-} \mathrm{N}$ concentration during dry season

On the contrary, in the dryer months (August, September)( Figure 03b), the increasing trend of $\mathrm{NO}_{3}{ }^{-} \mathrm{N}$ accumulation of lower tank could not be detected as there had not been continuous water flows into the last sampling points, hence, some $\mathrm{NO}_{3}{ }^{-} \mathrm{N}$ could accumulate in water in several places. The $\mathrm{NO}_{3}{ }^{-} \mathrm{N}$ values observed in the waters of tanks indicated lower values than permissible level of 10 ppm $\mathrm{NO}_{3}{ }^{-} \mathrm{N}$ (WHO, 1984) value despite the high application rate of chemical fertilizer. Profound growth of plants such as Ipomoea spp and Salvinia were present along the banks of canals (figure 04b) even during the period of non-cultivation as also reported by Young et al, 2009. This process may reduce the nitrogen content especially during dry season where surface water passing rate is very low. This phenomenon is equally applicable to other nutrients as well.

Another interesting phenomenon was observed in the nutrients movement with the water flow from one tank to another via commanding area. $\mathrm{NO}_{3}{ }^{-} \mathrm{N}$ concentration of water showed an increasing trend while passing through paddy fields and thus highest concentration was detected at the third sampling location (Alistana field R3 and Meegasagama field R3). However, there was a marginal decline between the third sampling location and the adjacent tank (Figure 04a). This may have been due to the dilution effect caused by large volume of tank water and the filtering effect of Thaulla which has several kinds of trees and creepers (Figure 04a) and many aquatic plants.

It was also found that the nutrient concentrations in waters of these three tanks showed a bimodal pattern which was coincided with the bimodal rainfall of the dry zone (Figure 5, Wijesundara et al, 2011a; 2011b). When temporal distribution is concerned, it was found that $\mathrm{NO}_{3}{ }^{-}-\mathrm{N}, \mathrm{PO}_{4}{ }^{3-} \mathrm{P}$ and $\mathrm{K}^{+}$concentrations of waters of these three tanks showed a bimodal pattern which was coincided with the bimodal rainfall of the dry zone. The water samples collected from the three sampling points along the paddy track of the commanding area of Meegasagama and Alistana tanks 
were also showed similar trend. Highest concentration of $\mathrm{NO}_{3}{ }^{-} \mathrm{N}, \mathrm{PO}_{4}{ }^{3-}-\mathrm{P}$ and $\mathrm{K}^{+}$ in waters of three tanks and sampling points of paddy track of the commanding area of Meegasagama and Alistana tanks was observed in months of April and May in Yala compared to the Maha season. Low nutrients concentration in the Maha period could be due to dilution effect caused by comparatively high volume of tank water during Maha season.

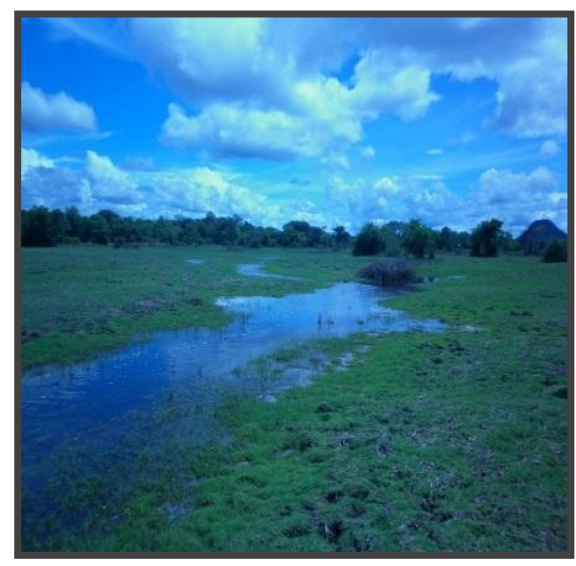

Figure 4a: Long distance water flow along tank thaulla

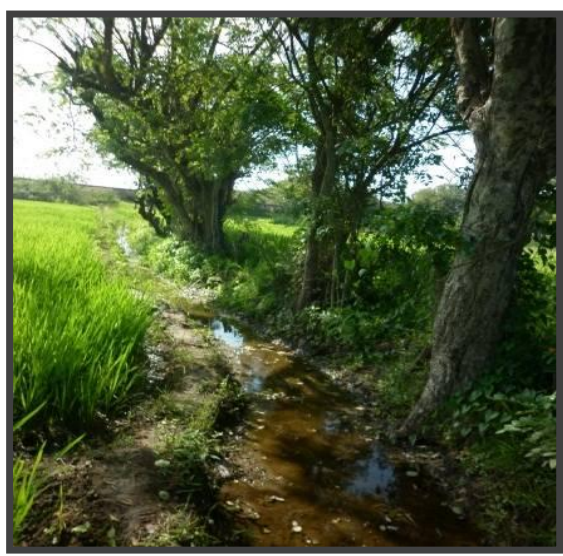

Figure 4b: Heavy growth of plants along the canals

However, the $\mathrm{NO}_{3}{ }^{-}-\mathrm{N}$ concentration did not exceed the permissible level of $10 \mathrm{mg} / \mathrm{L}$ for drinking (WHO, 1984) and thus for irrigation water as well.

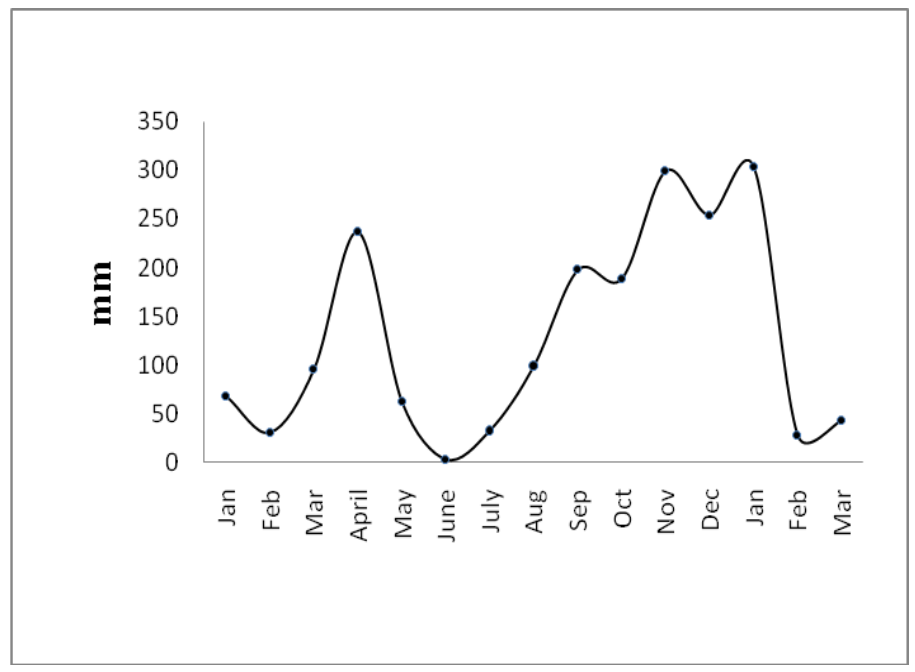

Figure 5: Bimodal pattern of rainfall distribution during 2010- 2011 
Concentration of $\mathrm{PO}_{4}{ }^{3-}-\mathrm{P}$ of the water of three tanks of the Thirappane cascade also showed a significant spatial and temporal variation during the study period (Table 02). Almost similar to $\mathrm{NO}_{3}{ }^{-}-\mathrm{N}$, concentrations, $\mathrm{PO}_{4}{ }^{3-}-\mathrm{P}$ concentrations in tank water were elevated in the months of April and May belonging to Yala season while relatively lower values were recorded for the Maha season. The $\mathrm{PO}_{4}{ }^{3-}-\mathrm{P}$ concentrations of the surface water ranged from $0.004-0.13 \mathrm{mgL}^{-1} \cdot \mathrm{PO}_{4}{ }^{3-}-\mathrm{P}$ is one of the major macro nutrients which is responsible for the eutrophication of open water bodies. $\mathrm{PO}_{4}{ }^{3-}-\mathrm{P}$ transport has found similar pattern with $\mathrm{NO}_{3}{ }^{-}-\mathrm{N}$, where the lowest content of $\mathrm{PO}_{4}{ }^{3-}-\mathrm{P}$ found within the maturity period of paddy (June, July) and the highest after the chemical fertilizer application (Yala season - April to May, Maha season -October to November) . After chemical fertilizer application, the contents of $\mathrm{PO}_{4}{ }^{3-}-\mathrm{P}$ increased remarkably and thereafter decreased gradually. The rate of $\mathrm{PO}_{4}{ }^{3-}-\mathrm{P}$ movement may have also influenced by land preparation. Since most of land management performed manually and machinery, this could have increased the sediment content in irrigation and draining water increasing $\mathrm{PO}_{4}{ }^{3-}-\mathrm{P}$ as well. During the study period, higher $\mathrm{PO}_{4}{ }^{3-}-\mathrm{P}$ values were observed during rainy period and highest values were detected at lower segments of paddy fields under each tank. This may be attributed to surface runoff during land preparation removing a considerable quantity of finer soil particles along with cattle dung and fertilizers from surrounding catchment areas.

For phosphates, the U.S Environmental protection agency suggests a critical value for occurrence of eutrophication is $0.08 \mathrm{ppm}$ (EPA, 1976). Although eutrophication is a natural process of aging of lakes and water bodies, human activities can also greatly accelerate eutrophication by letting nutrients and organic substances added (Tamot and Sharma, 2006). None of the tank water exceeded the EPA suggested value $0.08 \mathrm{ppm}$ except the month of April at which basal phosphate fertilizers are added to the paddy fields. $\mathrm{PO}_{4}{ }^{3-}-\mathrm{P}$ concentration showed an increasing trend while passing through paddy fields and highest concentration was detected in the third sampling location showing a subsequent decreasing trend of while passing through Thaulla area as similar to $\mathrm{NO}_{3}{ }^{-}-\mathrm{N}$. Field R1 located in upper part of Meegasagama tank showed lower contents of $\mathrm{PO}_{4}{ }^{3-}$-Pcompared to that of other fields located in lower position. A fairly high $\mathrm{K}^{+}$concentration was detected in surface water falling within the range of $2.01-8.16 \mathrm{mgL}^{-1}$, where the permissible level is $2 \mathrm{mg} / \mathrm{L}$ according to WHO standards (WHO, 1984). Concentration of $\mathrm{K}^{+}$in the water of three tanks of the Thirappane cascade also showed a significant spatial variation during the study period (Table 03). Similar to the $\mathrm{NO}_{3}{ }^{-} \mathrm{N}$ and $\mathrm{PO}_{4}{ }^{3-}-\mathrm{P}$, concentrations, $\mathrm{K}^{+}$concentrations in surface water were higher in the months of April and May within the Yala season while relatively low values were recorded for the Maha season. Similar elevated contents of $\mathrm{K}^{+}$have been observed during the seed sowing period by Gunawardana and Kumuduni, (1980) as well. Similar to $\mathrm{NO}_{3}{ }^{-}-\mathrm{N}$ and $\mathrm{PO}_{4}{ }^{3-}-\mathrm{P}, \mathrm{K}^{+}$concentration also showed an increasing trend while nutrient moving through paddy fields and highest values were observed in third sampling location. 
Table 2: Phosphate phosphorus $\left(\mathrm{PO}_{4}{ }^{3-} \mathrm{P} \mathrm{mgL}^{-1}\right)$ movement through Thirappane tank cascade during 2010 - 2011

\begin{tabular}{|c|c|c|c|c|c|c|c|c|c|c|c|c|}
\hline & Feb & Mar & April & May & June & July & Aug & Sep & Oct & Nov & Dec & Jan \\
\hline Mee Tank & $0.01_{\mathrm{D}}^{\mathrm{b}}$ & $0.03_{B}{ }^{d}$ & $0.04_{\mathrm{A}}{ }^{\mathrm{e}}$ & $0.04_{A}{ }^{e f}$ & $0.01_{D}{ }^{d}$ & $0.01_{D}{ }^{d}$ & $0.01_{D}{ }^{d}$ & $0.01_{D}{ }^{d}$ & $0.02{ }_{C}{ }^{f}$ & $0.02{ }_{\mathrm{C}}{ }^{\mathrm{f}}$ & $0.01_{D}^{b}$ & $0.01_{D}^{b}$ \\
\hline Field R1 & $0.01_{\mathrm{CD}}^{\mathrm{b}}$ & $0.04_{B}{ }^{c}$ & $0.04_{B}{ }^{e}$ & $0.05_{\mathrm{A}}^{\mathrm{d}}$ & $0.02_{C}{ }^{d}$ & $0.02_{C}{ }^{c}$ & $0.01_{\mathrm{CD}}^{\mathrm{d}}$ & $0.01_{\mathrm{CD}}^{\mathrm{d}}$ & $0.02{ }_{\mathrm{C}}{ }^{\mathrm{f}}$ & $0.02_{\mathrm{C}}{ }^{\mathrm{f}}$ & $0.02_{C}{ }^{b}$ & $0.01_{\mathrm{CD}}^{\mathrm{b}}$ \\
\hline Field R2 & $0.006_{\mathrm{E}}^{\mathrm{b}}$ & $0.06_{\mathrm{B}}^{\mathrm{b}}$ & $0.06_{B}{ }^{d}$ & $0.07_{\mathrm{A}}^{\mathrm{bc}}$ & $0.02_{\mathrm{D}}^{\mathrm{d}}$ & $0.02_{\mathrm{D}}^{\mathrm{c}}$ & $0.03_{\mathrm{C}}^{\mathrm{abc}}$ & $0.02_{\mathrm{D}}^{\mathrm{c}}$ & $0.03_{C}{ }^{\text {ef }}$ & $0.03_{C}{ }^{\mathrm{de}}$ & $0.03_{\mathrm{C}}^{\mathrm{b}}$ & $0.006_{\mathrm{E}}^{\mathrm{b}}$ \\
\hline Field R3 & $0.05_{\mathrm{BC}}^{\mathrm{a}}$ & $0.08_{\mathrm{B}}{ }^{\mathrm{a}}$ & $0.13_{\mathrm{A}}^{\mathrm{ab}}$ & $0.13_{\mathrm{A}}{ }^{\mathrm{a}}$ & $0.05_{\mathrm{C}}^{\mathrm{bc}}$ & $0.01_{\mathrm{E}}^{\mathrm{d}}$ & $0.04_{\mathrm{C}}{ }^{\mathrm{a}}$ & $0.03_{\mathrm{D}}^{\mathrm{b}}$ & $0.05_{\mathrm{C}}^{\mathrm{cd}}$ & $0.04_{\mathrm{CD}}^{\mathrm{ab}}$ & $0.03_{\mathrm{D}}^{\mathrm{b}}$ & $0.05_{\mathrm{C}}{ }^{\mathrm{a}}$ \\
\hline Alis tank & $0.006_{\mathrm{F}}^{\mathrm{b}}$ & $0.03_{\mathrm{CD}}^{\mathrm{d}}$ & $0.08_{\mathrm{A}}{ }^{\mathrm{c}}$ & $0.05_{B}{ }^{\mathrm{de}}$ & $0.04_{\mathrm{BC}}{ }^{\mathrm{c}}$ & $0.01_{\mathrm{E}}^{\mathrm{d}}$ & $0.03_{\mathrm{C}}^{\mathrm{abc}}$ & $0.02_{\mathrm{D}}^{\mathrm{cd}}$ & $0.04_{B C}^{\text {de }}$ & $0.03_{C}{ }^{e}$ & $0.02_{D}{ }^{b}$ & $0.006_{\mathrm{F}}^{\mathrm{b}}$ \\
\hline field R1 & $0.004_{\mathrm{E}}^{\mathrm{b}}$ & $0.03_{\mathrm{B}}{ }^{\mathrm{d}}$ & $0.07_{\mathrm{A}}^{\mathrm{cd}}$ & $0.03_{\mathrm{BC}}{ }^{\mathrm{f}}$ & $0.02_{C}{ }^{d}$ & $0.01_{D}{ }^{d}$ & $0.02_{\mathrm{BC}}^{\mathrm{bcd}}$ & $0.01_{D}{ }^{d}$ & $0.02_{\mathrm{C}}{ }^{\mathrm{f}}$ & $0.03_{\mathrm{B}}{ }^{\mathrm{e}}$ & $0.02_{\mathrm{C}}^{\mathrm{b}}$ & $0.004_{\mathrm{E}}^{\mathrm{b}}$ \\
\hline Field R2 & $0.008_{\mathrm{E}}^{\mathrm{b}}$ & $0.05_{B}{ }^{c}$ & $0.08_{\mathrm{A}}{ }^{\mathrm{c}}$ & $0.05_{B}{ }^{d}$ & $0.05_{\mathrm{B}}^{\mathrm{bc}}$ & $0.03_{\mathrm{CD}}^{\mathrm{b}}$ & $0.04_{C}{ }^{a b}$ & $0.02_{\mathrm{D}}^{\mathrm{bc}}$ & $0.07_{\mathrm{AB}}^{\mathrm{bc}}$ & $0.04_{C}{ }^{c d}$ & $0.04_{C}{ }^{b}$ & $0.008_{\mathrm{E}}^{\mathrm{b}}$ \\
\hline Field R3 & $0.01_{\mathrm{E}}^{\mathrm{b}}$ & $0.07_{\mathrm{C}}{ }^{\mathrm{a}}$ & $0.13_{\mathrm{A}}{ }^{\mathrm{a}}$ & $0.08_{B}{ }^{b}$ & $0.06_{\mathrm{CD}}^{\mathrm{a}}$ & $0.05_{\mathrm{D}}{ }^{\mathrm{a}}$ & $0.04_{\mathrm{D}}{ }^{\mathrm{a}}$ & $0.04_{\mathrm{A}}{ }^{\mathrm{a}}$ & $0.12_{\mathrm{A}}{ }^{\mathrm{a}}$ & $0.05_{\mathrm{CD}}^{\mathrm{a}}$ & $0.10_{\mathrm{AB}}^{\mathrm{a}}$ & $0.01_{\mathrm{E}}^{\mathrm{b}}$ \\
\hline Thi tank & $0.007_{\mathrm{F}}^{\mathrm{b}}$ & $0.05_{C}{ }^{c}$ & $0.11_{\mathrm{A}}^{\mathrm{b}}$ & $0.07_{\mathrm{B}}^{\mathrm{c}}$ & $0.06_{\mathrm{BC}}^{\mathrm{ab}}$ & $0.05_{\mathrm{C}}^{\mathrm{a}}$ & $0.02_{\mathrm{E}}^{\mathrm{cd}}$ & $0.02_{\mathrm{E}}^{\mathrm{bc}}$ & $0.07_{\mathrm{B}}^{\mathrm{b}}$ & $0.04_{D}^{b c}$ & $0.03_{\mathrm{DE}}^{\mathrm{b}}$ & $0.007_{\mathrm{F}}^{\mathrm{b}}$ \\
\hline
\end{tabular}

Means with same letters are not statistically significant. (Lowercase letters- Temporal variation, Upper case letters- Spatial variation).(Thi tankThirappane tank, Alis tank- Alisthana tank, Mee tank- Meegasagama tank) 
Table 3: Potassium $\left(\mathrm{K}^{+} \mathrm{mgL}^{-1}\right)$ movement through Thirappane tank cascade during 2010- 2011

\begin{tabular}{|c|c|c|c|c|c|c|c|c|c|c|c|c|}
\hline & Feb & Mar & April & May & June & July & Aug & Sep & Oct & Nov & Dec & Jan \\
\hline Mee Tank & $2.01_{\mathrm{G}}{ }^{\mathrm{d}}$ & $2.90_{\mathrm{F}}^{\mathrm{e}}$ & $7.28_{\mathrm{A}}{ }^{\mathrm{f}}$ & $7.00_{\mathrm{AB}}^{\mathrm{g}}$ & $6.39_{\mathrm{B}}{ }^{\mathrm{f}}$ & $5.25_{\mathrm{C}}^{\mathrm{f}}$ & $2.84_{\mathrm{F}}{ }^{\mathrm{f}}$ & $2.15_{\mathrm{G}}{ }^{\mathrm{d}}$ & $3.75_{\mathrm{E}}^{\mathrm{g}}$ & $6.28_{\mathrm{B}}{ }^{\mathrm{f}}$ & $6.47_{\mathrm{B}}^{\mathrm{h}}$ & $5.00_{\mathrm{D}}^{\mathrm{h}}$ \\
\hline Field R1 & $2.15_{\mathrm{H}}^{\mathrm{c}}$ & $3.09_{\mathrm{GH}}^{\mathrm{d}}$ & $7.49_{\mathrm{A}}^{\mathrm{e}}$ & $7.18_{B}{ }^{f}$ & $6.43_{C}{ }^{f}$ & $5.38_{\mathrm{D}}{ }^{\text {ef }}$ & $3.16_{\mathrm{GH}}^{\mathrm{e}}$ & $2.07_{\mathrm{H}}^{\mathrm{d}}$ & $3.85_{\mathrm{F}}^{\mathrm{fg}}$ & $6.38_{C}{ }^{f}$ & $6.60_{\mathrm{BC}} \mathrm{g}^{\mathrm{g}}$ & $5.10_{\mathrm{E}}^{g}$ \\
\hline Field R2 & $2.32^{b}{ }^{b}$ & $3.45_{\mathrm{G}}{ }^{\mathrm{c}}$ & $7.76_{A}{ }^{d}$ & $7.39_{\mathrm{B}}^{\mathrm{e}}$ & $6.78_{\mathrm{CD}}^{\mathrm{e}}$ & $5.53_{\mathrm{D}}^{\mathrm{de}}$ & $3.39_{\mathrm{GH}}{ }^{\mathrm{cd}}$ & $2.30_{\mathrm{C}}^{\mathrm{c}}$ & $3.92_{\mathrm{F}}^{\mathrm{e}}$ & ${ }_{\mathrm{e}}^{6.68_{\mathrm{CD}}}$ & $6.85_{\mathrm{C}}{ }^{\mathrm{f}}$ & $5.35_{\mathrm{E}}^{\mathrm{f}}$ \\
\hline Field R3 & $2.47_{\mathrm{H}}^{\mathrm{a}}$ & $3.71_{\mathrm{G}}^{\mathrm{b}}$ & $8.07_{\mathrm{A}}^{\mathrm{c}}$ & $7.67_{\mathrm{B}}^{\mathrm{c}}$ & $7.37_{\mathrm{BC}}{ }^{\mathrm{bc}}$ & $5.76_{\mathrm{E}}^{\mathrm{c}}$ & $3.79_{\mathrm{G}}{ }^{\mathrm{a}}$ & $2.47_{\mathrm{H}}^{\mathrm{b}}$ & $4.21_{\mathrm{F}}^{\mathrm{cd}}$ & $6.88_{\mathrm{D}}^{\mathrm{c}}$ & $7.19^{d}{ }^{d}$ & $5.75_{\mathrm{E}}^{\mathrm{c}}$ \\
\hline Alis tank & $2.15_{\mathrm{G}}^{\mathrm{c}}$ & $3.40_{\mathrm{F}}^{\mathrm{c}}$ & $7.66_{\mathrm{A}}^{\mathrm{de}}$ & $7.50_{A B}{ }^{d}$ & $7.18_{B C}{ }^{d}$ & $5.64_{D}{ }^{\mathrm{cd}}$ & $3.22_{\mathrm{F}}^{\mathrm{e}}$ & $2.31_{\mathrm{G}}{ }^{\mathrm{c}}$ & $4.06_{\mathrm{E}}^{\mathrm{e}}$ & $e_{e}^{6.71_{C}{ }^{d}}$ & $6.92_{C}{ }^{\text {ef }}$ & $5.56_{\mathrm{D}}{ }^{\mathrm{e}}$ \\
\hline field R1 & $2.21_{\mathrm{G}}{ }^{\mathrm{c}}$ & $3.47_{\mathrm{F}}^{\mathrm{c}}$ & $7.80_{\mathrm{A}}^{\mathrm{d}}$ & $7.52_{\mathrm{B}}^{\mathrm{d}}$ & $7.26_{\mathrm{B}}{ }^{\mathrm{cd}}$ & $5.79_{\mathrm{D}}^{\mathrm{c}}$ & $3.28_{\mathrm{F}}^{\mathrm{de}}$ & $2.28_{\mathrm{G}}{ }^{\mathrm{c}}$ & $4.13_{\mathrm{E}}^{\mathrm{de}}$ & $6.86_{C}^{c}$ & $6.97_{\mathrm{BC}}^{\mathrm{e}}$ & $5.67_{\mathrm{D}}{ }^{\mathrm{C}}$ \\
\hline Field R2 & $2.34_{\mathrm{I}}^{\mathrm{b}}$ & $3.80_{\mathrm{GH}}^{\mathrm{b}}$ & $8.17_{\mathrm{A}}^{\mathrm{bc}}$ & $7.71_{B}{ }^{c}$ & $7.48_{\mathrm{BC}}^{\mathrm{b}}$ & $6.21_{\mathrm{E}}^{\mathrm{b}}$ & $3.48_{\mathrm{H}}^{\mathrm{bc}}$ & $2.49_{\mathrm{I}}^{\mathrm{b}}$ & $\begin{array}{l}4.29_{\mathrm{G}}^{\mathrm{b}} \\
\mathrm{c}\end{array}$ & $7.00_{\mathrm{D}}^{\mathrm{b}}$ & $7.38_{\mathrm{C}}{ }^{\mathrm{c}}$ & $5.91_{\mathrm{F}}^{\mathrm{b}}$ \\
\hline Field R3 & $2.50_{\mathrm{H}}{ }^{\mathrm{a}}$ & $4.19_{\mathrm{F}}{ }^{\mathrm{a}}$ & $8.54_{\mathrm{A}}{ }^{\mathrm{a}}$ & $8.16_{\mathrm{AB}}{ }^{\mathrm{a}}$ & $7.79_{\mathrm{B}}{ }^{\mathrm{a}}$ & $6.55_{\mathrm{D}}^{\mathrm{a}}$ & $3.77_{\mathrm{G}}{ }^{\mathrm{a}}$ & $2.76_{\mathrm{H}}{ }^{\mathrm{a}}$ & $4.71_{\mathrm{E}}^{\mathrm{a}}$ & $7.27_{\mathrm{C}}^{\mathrm{a}}$ & $7.69_{\mathrm{B}}^{\mathrm{a}}$ & $6.40_{\mathrm{D}}^{\mathrm{a}}$ \\
\hline Thi tank & $2.43_{\mathrm{I}}^{\mathrm{a}}$ & $3.72_{\mathrm{FG}}^{\mathrm{b}}$ & $8.28_{\mathrm{A}}^{\mathrm{b}}$ & $7.19_{\mathrm{BC}}^{\mathrm{b}}$ & $7.33_{\mathrm{B}}{ }^{\mathrm{c}}$ & $6.23_{\mathrm{E}}^{\mathrm{b}}$ & $3.52_{\mathrm{G}}^{\mathrm{b}}$ & $2.65_{\mathrm{H}}^{\mathrm{a}}$ & $4.33_{\mathrm{F}}^{\mathrm{b}}$ & $6.81_{D}{ }^{c d}$ & $7.56_{\mathrm{B}}^{\mathrm{b}}$ & $6.37_{\mathrm{E}}^{\mathrm{a}}$ \\
\hline
\end{tabular}

Means with same letters are not statistically significant. (Lowercase letters- Temporal variation, Upper case letters- Spatial variation) (Thi tank- Thirappane tank, Alis tank- Alisthana tank, Mee tank- Meegasagama tank) 
Those phenomena indicate that the amounts of nutrient applied might be sufficient for upper parts of the cascades. However, it seems to be in excess in the lower parts as the surface run off also carrying considerable amounts of $\mathrm{N}, \mathrm{P}$ and $\mathrm{K}$ suggesting a reduction in the quantity of fertilizer to be used by giving attention to the available quantities in irrigation water.

\section{Conclusions}

The water flow of a tank cascade system is not just carrying some amount of nutrients to the lower elevations, but also a considerable amount of sediments as well. Highest nutrients $\left(\mathrm{NO}_{3}{ }^{-}-\mathrm{N}, \mathrm{PO}_{4}{ }^{3-}-\mathrm{P}\right.$ and $\left.\mathrm{K}^{+}\right)$contents were observed just after application of chemical fertilizer during Yala and Maha seasons and showed an increasing trend while they are passing through paddy fields. However, the third sampling location showed highest values and there was a marginal decline between the third sampling location and the adjacent tank. This marginal decline of nutrients could be due to the dilution effect caused by relatively large volume of water in the tanks and the effect of Thaulla which may act as a filter for excess nutrients of the water passing through it. During dryer months, as there is lack of a continuous water flow, an accumulation of nutrients in several locations were possible. During the cultivation period, continuous water flow facilitated a higher transport of nutrients proved by the highest values observed at last sampling point at the most lowest elevation.

The merit of this cascade system is the buffering of the effects of anthropogenic activities so that any nutrient is not allowed to exceed the scientifically accepted permissible levels. With the disappearance of so many basic features of cascade systems, it exists and performs successfully even up to date, and hence would be the proper time to take necessary steps to re-strength and maintain the basic features required for a tank cascade system giving prominence to micro land uses of the cascade such as Godawela, Katakaduwa, Kiulela, Iswatiya, and Perahana etc.

However, in the latter part of the cascade, surface water tends to carry high loads of nutrients. To avoid this demerit of the system, the chemical fertilizer may be applied based on site specific characteristics relating to soils and water as well.

\section{References}

Panabokke, C. R. (2002). "The small tank cascade systems of Rajarata: their, distribution patterns and hydrography” IWMI-MASL Publication. ISBN 955-9185-06-3. 7-8.

Shinogi, Y. (2001). "Optimal water management of tank cascade system" International Commission on Irrigation and Drainage, $1^{\text {st }}$ Asian Regional Conference, Seoul.

Young, S. M., A. Pitawala and S. Gunathilaka (2010). "Fate of phosphate and nitrate in waters of an intensive agricultural area in the Dry Zone of Sri Lanka" Paddy Water Environment, 8: 71-79. 
Turner, R. E. and N. N. Rabelais (2004). "Suspended sediment, C, N, P and Si yields from Mississippi river basin” Hydrobiology, 511: 78-89.

William, H. R., J. V. Michale, Z. Qianyi and P. Jon (2000). "Water quality trends and changing agricultural practices in a Midwest U.S watershed 1994-2006" Journal of Environmental Quality, 37: 1862-1874.

Darma, D., S. Yasin and T. Masunaga (2011). "Nutrient movement characteristic in terrace sawah occupied by cascade irrigation system in West Sumatra Indonesia" Journal of Ecology and the Natural Environment, 3(4): 139-148.

U. S. Environmental Protection Agency (1976). "Quality Criteria for water" U.S. Environment protection Agency, Washington D.C.

Tamot, S. and P. Sharma (2006). "Physico-chemical status of upper lake (Bhopal, India) water quality with special reference to Phosphate and Nitrate concentration and their Impact on lake ecosystem" Asian Journal of Experimental Sciences, 20(1): 151-158.

WHO, (1984) “Guideline for drinking water quality” World Health Organization, Geneva.

Chun, G. Y., H. H. Jong and J. H. Jeon (2003). "Mass balance analysis in Korean paddy rice culture" Paddy Water Environment, 1: 99-103.

Gunawardhana, H. D. and R. N. Kumauni (1986). "Studies on quality of irrigation water under Kalawewa area” Journal National Science Council, Sri Lanka 9(2).

Murply, J. and J. P. Riley (1962). “Anal.chem.Acta.27-31 In: Hesse, P.R. 1971”. “A text book of Soil Chemical analysis” John Murray (publishers) Ltd., London.

Bremner, J. M. and C. S. Muloaney (1982). "In methods of soil analysis" Part $2.2^{\text {nd }}$ ed. Agronomy No.09, American society of Agronomy, Madison, WI, USA.

Wijesundara, W. M. G. D., K. A. Nandasena and A. N. Jayakody (2011a). "Temporal variation of plant nutrients and some water quality parameters in Meegassagama tank" Proceedings of the $10^{\text {th }}$ International conference of the East and Southeast Asia federation of Soil Science Societies, 65-66.

Wijesundara, W. M. G. D., K. A. Nandasena and A. N. Jayakody (2011b). "Temporal variation of nitrate and phosphate in selected six small tanks of Dry Zone of Sri Lanka" $23^{\text {rd }}$ Annual congress, Post Graduate Institute of Agriculture, Peradeniya. 